\title{
Pengaruh Keterampilan Dasar Mengajar Guru Terhadap Perilaku Disiplin Pada Anak Usia Dini Kelompok B
}

\author{
Sri Karina Elprida ${ }^{1}$, I Wayan Sujana ${ }^{2}$, Luh Ayu Tirtayani ${ }^{3}$ \\ 1,3 Jurusan Pendidikan Guru Pendidikan Anak Usia Dini \\ 2 Jurusan Pendidikan Guru Sekolah Dasar \\ Universitas Pendidikan Ganesha \\ Singaraja, Indonesia \\ e-mail: karinaelprida11@gmail.com¹, iwayan.sujana@undiksha.ac.id ${ }^{2}$ \\ ayu.tirtayani@undiksha.ac.id ${ }^{3}$
}

\begin{abstract}
Abstrak
Penelitian ini bertujuan untuk mengetahui pengaruh keterampilan dasar mengajar guru terhadap perilaku disiplin anak. Penelitian ini menggunakan bentuk Pre-Experimental designs, dengan one-group pretestposttest design. Populasi penelitian ini adalah seluruh anak kelompok B1 TK Ganesha Denpasar berjumlah 20 orang. Teknik sampel yang digunakan adalah sampel jenuh sehigga sampel berjumlah sama dengan populasi. Pengumpulan data dilakukan dengan observasi dan dianalisis menggunakan analisis uji-t. Hasil penelitian menunjukkan nilai rata-rata post-test lebih tinggi dari pada nilai rata-rata pre-test $(85,25>71,50)$. Selanjutnya, diperoleh nilai $t_{\text {hitung }}=18,485$, dan berdasarkan taraf sigifikansi $5 \%$ dengan $(\mathrm{dk}=19)$, maka diperoleh $\mathrm{t}_{\text {tabel }}=2,093$, ini menunjukkan bahwa nilai $\mathrm{t}_{\text {hitung }}>\mathrm{t}_{\text {tabel }}$, hal ini berarti $\mathrm{H}_{0}$ yang menyatakan tidak terdapat pengaruh yang signifikan penerapan keterampilan dasar mengajar guru terhadap perilaku disiplin anak kelompok B1 di TK Ganesha Denpasar ditolak, Dengan demikian, disimpulkan bahwa penerapan keterampilan dasar mengajar guru berpengaruh terhadap perilaku disiplin anak Kelompok B1 TK Ganesha Denpasar Tahun Pelajaran 2017/2018.
\end{abstract}

Kata-kata kunci : keterampilan dasar mengajar guru, perilaku disiplin, anak usia dini

\begin{abstract}
The research is aimed to perceive the influences of teacher basic teaching skill applications to child disciplinary behavior.This type of research is Pre-Experimental designs, and used with one-group pretest-posttest design. The population in this research is all children of B1 TK Ganesha Denpasar amounted to 20 people. The sample technique used is sampling jenuh so the sample is the same as the population. The data was collected by using with form of observation and analyzed using t-test analysis. The results showed that the post-test average was higher than the average pre-test $(85,25>71,50)$. Next, obtained $t_{\text {count }}=25,18$ and based on the level of significance of $5 \%$ with (dk $\left.=19\right)$, then obtained $t_{\text {table }}=2,093$. This indicates that the value of $t_{\text {count }}>t_{\text {table }}$, this means $H_{0}$ which states there is no significant effect of teacher basic teaching skill applications to B1 children disciplinary behavior in TK Ganesha Denpasar is rejected.Thus, it was concluded that the application of teacher basic teaching skill applications had an effect on the discipline behavior of B1 group children in Ganesha Denpasar Kindergarten academic year 2017/2018.
\end{abstract}

Keywords: teacher basic teaching skill, discipline behavior, early childhood 


\section{PENDAHULUAN}

Usia dini merupakan masa dimana semua aspek dalam diri manusia sedang mengalami perkembangan sesuai dengan pertumbuhannya. Usia dini merupakan masa dimana semua aspek dalam diri manusia sedang mengalami perkembangan sesuai dengan pertumbuhannya. Dalam dunia psikologi disebutkan bahwa anak usia dini merupakan masa yang sangat cemerlang untuk dilakukannya pendidikan. Para ahli psikologi menyebutnya dengan istilah usia emas (golden age). "Lima puluh persen keberagaman kecerdasan orang dewasa sudah terjadi ketika anak berusia empat tahun. Peningkatan tiga puluh persen berikutnya terjadi pada usia delapan tahun, dan dua puluh persen sisanya pada pertengahan atau akhir dasawarsa kedua" (Fidesrinur 2015:10). Salah satu pendidikan yang sangat penting dikenalkan sejak usia dini yaitu pendidikan yang mengembangkan sosial emosional anak. rentang usia 0-6 tahun.

Menurut Daniel (Fidesrinur, 2015:10) "keberhasilan seseorang dimasyarakat sebagian besar ditentukan oleh kecerdasan emosi $(80 \%)$, dan kecerdasan kognitif hanya 20\%". Menurut (Fidesrinur, 2015:3) memiliki perilaku hidup sehat, rasa ingin tahu, kreatif dan estetis, percaya diri, disiplin, mandiri, peduli, mampu bekerja sama, mampu menyesuaikan diri, jujur, dan santun dalam berinteraksi dengan orang lain merupakan cerminan kecerdasan sosial-emosional sebagai sikap dan perilaku yang mengenal perasaan diri, orang lain, dan nilai-nilai sosial yang sesuai dengan norma serta budaya yang berlaku. Pendapat tersebut berarti bahwa perilaku disiplin merupakan salah satu penunjang keberhasilan seseorang karena perilaku disiplin merupakan salah satu contoh dari kecerdasan emosi. Dengan membiasakan anak berperilaku disiplin diharapkan bahwa ketika anak tumbuh dewasa, meraka akan menjadi manusia-manusia yang tidak saja pandai dan berpengetahuan luas, namun juga bermoral tinggi, dan berakhlak mulia, serta berbudi luhur.

Sikap yang mencerminkan perilaku disiplin yaitu "sikap taat terhadap aturan sehari-hari serta sikap sabar" Fidesrinur
(2015:6-7). Sikap taat terhadap aturan ditunjukkan dengan perilaku anak yang bersedia mengikuti aturan secara sadar tanpa paksaan, tidak marah ketika diingatkan aturan oleh temannya, dan mengingatkan temanya bila bertindak tidak sesuai aturan.

Sikap sabar terlihat pada perilaku anak yang menunjukkan kesedian diri untuk menahan diri, bersikap tenang, tidak lekas marah dan dapat menunda keinginan, sikap mau menunggu giliran, mau mendengarkan ketika orang lain berbicara, tidak menangis saat berpisah dengan ibunya, tidak mudah mengeluh, tidak tergesa-gesa, selalu menyelesaikan gagasannya hingga tuntas, dan berusaha tidak menyakiti atau membalas dengan kekerasan.

Perilaku disiplin dapat dikenalkan dan dibiasakan dirumah dan sekolah, oleh karena itu harus ada kerja sama yang baik antara guru dan orang tua. Banyak faktor yang dapat mempengaruhi perilaku disiplin. Dalam penelitian yang dilakukan oleh Astiti (2017) menyatakan bahwa rendahnya nilai karakter yang dimiliki oleh anak disebabkan oleh bagaimana pengelolaan pembelajaran yang diberikan oleh guru serta sarana dan prasarana yang terbatas. Dari pendapat tersebut dapat berarti bahwa guru harus terampil dalam mengajar di dalam kelas.

$$
\text { Menurut Saud (2010:55), }
$$
keterampilan dasar mengajar guru dalam proses belajar mengajar antara lain: keterampilan membuka dan menutup pelajaran, keterampilan menjelaskan, keterampilan bertanya, keterampilan memberi penguatan, keterampilan membimbing diskusi kelompok kecil, keterampilan mengelola kelas, keterampilan mengadakan variasi, keterampilan mengajar perorangan dan kelompok kecil. Dari pendapat diatas dapat diartikan bahwa keterampilan dasar mengajar guru memiliki delapan jenis keterampilan yang harus diterapkan guru dalam proses belajar mengajar. Dengan diterapkannya keterampilan dasar mengajar yang lebih konsisten diharapkan akan berpengaruh kepada peningkatan perilaku disiplin yang ditunjukkan anak disekolah. 
Berdasarkan hasil observasi yang dilakukan di TK Ganesha Denpasar Tahun Pelajaran 2017/2018 menunjukkan bahwa fakta dilapangan belum sesuai dengan harapan yang telah disebutkan. Beberapa anak di kelompok B1 sering menunjukkan perilaku yang kurang disiplin seperti tidak tertib dalam mengerjakan tugas atau megikuti kegiatan di sekolah, tidak menaati aturan disekolah, mudah marah dan membalas dengan kekerasan, tidak sabar dalam menunggu giliran, mudah menangis, tergesa-gesa dalam mengerjakan tugas, dan mudah mengeluh dalam mengerjakan tugas.

Berdasarkan hasil wawancara, guru kelompok B1 dapat dikatakan bahwa guru kurang memahami tentang keterampilan dasar mengajar serta harus diingatkan kembali tentang cara-cara penerapannya. Selain itu nilai perilaku disiplin anak B1 juga masih rendah, dimana dari 20 orang anak $30 \%$ diantaranya mendapat nilai bintang 2 $\left({ }^{* *}\right)$ dan $60 \%$ mendapat bintang $3\left(^{* * *}\right)$, dan $10 \%$ mendapatkan bintang $4\left(^{* * *}\right)$, sedangkan harapan ketuntasan yang berkaitan dengan perilaku disiplin yaitu anak mampu memperoleh bintang $4\left(^{* * * *}\right)$ dengan demikian perilaku disiplin anak perlu ditingkatkan. Berdasarkan masalah di atas diduga bahwa keterampilan dasar mengajar guru berpengaruh kepada nilai perilaku disiplin, karena keterampilan mengajar seorang guru mempengaruhi banyak hal dalam pembelajaran disekolah salah satunya yaitu perilaku disiplin anak.

Keterampilan dasar mengajar guru (teaching skill) yang sering disebut juga dengan keterampilan mengajar sangatlah penting dalam melaksanakan pembelajaran untuk kelancaran proses belajar-mengajar. "Teaching skills can be defined as discrete and coherent activities by teachers which foster pupil learning" (Kriyacou 2007:4). Pendapat tersebut berarti bahwa keterampilan mengajar dapat didefinisikan sebagai aktivitas yang diskrit dan koheren yang dilakukan oleh guru untuk mendorong pembelajaran anak. Dari pendapat diatas dapat kita tau bahwa keterampilan mengajar merupakan beberapa aktivitas atau kegiatan yang berbeda namun masih saling berkaitan yang dilakukan oleh guru untuk mendorong pembelajaran anak.

selain itu, keterampilan dasar mengajar juga dapat didefinisikan sebagai "kemampuan minimal yang harus dicapai oleh calon guru" (Suwarna, 2006:66).

Sedangkan, guru menurut UndangUndang No.14 Tahun 2015 adalah "pendidik profesional denga tugas utama mendidik, mengajar, membimbing, mengarahkan, melatih, menilai, dan mengevaluasi peserta didik pada anak usia dini jalur pendidikan formal, pendidikan dasar dan pendidikan menengah". Berdasarkan beberapa pendapat diatas, dapat disimpulkan bahwa keterampilan dasar mengajar guru merupakan kemampuan minimal dalam kegiatan atau aktivitas yang kompleks namun masih saling berkaitan yang harus dimiliki tenaga pendidik profesional (guru) untuk menunjang pembelajaran anak.

Keterampilan dasar mengajar guru yang diterapkan dalam penelitian ini hanya sebatas pada menerapkan tiga keterampilan dasar mengajar guru, yang meliputi: keterampilan bertanya, keterampilan memberi penguatan, keterampilan mengelola kelas. Bertanya dalam perspektif pembelajaran dapat didefinisikan "sebagai strategi yang digunakan oleh guru untuk membantu siswa dalam mengembangkan dan menggunakan berbagai keterampilan berpikir "(Rasto 2015:92). Keterampilan bertanya merupakan "keterampilan yang digunakan untuk mendapatkan jawaban atau balikan dari orang lain" (Barnawi, 2012:202).

Menurut Saud (2010:62) keterampilan bertanya dibedakan atas keterampilan bertanya tingkat dasar dan keterampilan bertanya tingkat lanjut. Keterampilan bertanya tingkat dasar ialah kemampuan guru dalam mengajukan pertanyaan untuk mengetahui daya ingat peserta didik. Sedangkan, keterampilan bertanya tingkat lanjut ialah kemampuan bertanya seorang guru dalam pembelajaran untuk mengetahui kemampuan berpikir peserta didik yang lebih kompleks.

Keterampilan memberi penguatan merupakan keterampilan yang sama 
pentingnya dengan keterampilan bertanya yang telah dijelaskan sebelumnya, dalam proses pembelajaran. Penguatan adalah "respon terhadap suatu tingkah laku yang dapat meningkatkan kemungkinan berulangnya kembali tingkah laku tersebut" (Saud, 2010: 65). Menurut Barnawi (2012) penguatan ialah respon positif dalam pembelajaran yang diberikan guru terhadap perilaku peserta didik yang positif dengan tujuan mempertahankan dan meningkatkan perilaku tersebut. Menurut Skinner (Rasto 2015:111) penguatan didefinisikan sebagai pemberian stimulus dalam rangka meningkatkan kemungkinan perilaku tertentu yang ditampilkan. Menurut Helmiati (2013:74) penguatan bersifat verbal ataupun nonverbal.

Sedangkan, Pengelolaan kelas adalah "keterampilan guru menciptakan dan memelihara kondisi belajar yang optimal dan mengembalikannya apabila terjadi gangguan dalam proses belajar mengajar" (Saud, 2010:69). Menurut Asril (2011:72-73) keterampilan mengelola kelas merupakan keterampilan guru unuk menciptakan dan memelihara kondisi belajar yang optimal dan mengembalikan ke kondisi yang optimal jika terjadi gangguan, baik dengan cara mendisiplinkan ataupun melakukan kegiatan remedial.

Menurut (Fidesrinur, 2015:6) dalam penanaman perilaku disiplin diperlukan $5 \mathrm{~K}$, yaitu (1) Konsensus, ada kesepakatan bersama antar guru dan orang tua tentang karakter yang akan dibangun dan cara membangunnya, (2) komitmen, ada ketaatan dan tanggung jawab bersama oleh guru dan orang tua dalam melaksanakan kesepakatan penerapan karakter pada anak (3) konsisten, ada keajegan dalam proses penerapan karakter melalui kegiatan bermain, baik di lembaga PAUD maupun di keluarga, (4) kontinu, dilakukan secara terus menerus sepanjang hari sepanjang tahun hingga perilaku tersebut menjadi kebiasaan selanjutnya terpatri dalam jiwa dan pikiran anak sehingga membentuk karakter, (5) konsekuen ada konsekuensi yang diterapkan dan harus dipatuhi baik oleh guru, orang tua, maupun anak bila terjadi pelanggaran terhadap komitmen pengembangan karakter anak. konsekuensi yang diterapkan untuk anak tidak bersifat hukuman fisik. Bentuk dan caranya dapat disepakati dengan anak, misalnya anak boleh memilih tidak menonton kartun kesukaannya atau membereskan tempat tidur.

Menurut Aulina (2013:42) faktor yang perlu diperhatikan dalam penanaman perilaku disiplin, salah satunya yaitu menghargai kebiasan baik dengan senyum, pelukan atau dengan menunjukkan ketertarikan pada apa yang anak lakukan, dalam hal ini keterampilan guru dalam memberi pengutan sangatlah penting dalam membangun perilaku disiplin. Hasil penelitian yang relevan dengan penelitian ini adalah penelitian yang dilakukan oleh Wahyuni (2015). Hasil penilitian yang dilakukan menunjukkan ada hubungan yang positif antara keterampilan mengajar guru dengan minat belajar siswa kelas $\mathrm{V}$ SD Negeri Segugus I Kecamatan Simpur Kabupaten Hulu Sungai Selatan Provinsi Kalimantan Selatan Tahun Ajaran 2014/2015. Semakin tinggi keterampilan mengajar guru maka semakin tinggi pula minat belajar siswa. Penelitian yang relevan dengan penelitian ini adalah penelitian yang dilaksanakan oleh Prastyaningarum (2014). Hasil penelitian yang dilakukan menunjukkan bahwa keterampilan bertanya guru memiliki pengaruh yang signifikan terhadap kemampuan berpikir kritis anak kelompok B di TK AL-HIDAYAH. Hal tersebut dibuktikan dengan adanya peningkatan kemampuan berpikir kritis pada saat sesudah perlakuan.

\section{METODE}

Penelitian ini dilaksanakan pada kelompok B1 TK Ganesha Denpasar Tahun Pelajaran 2017/2018. Penelitian ini pada dasarnya bertujuan untuk mengetahui pengaruh signifikansi penerapan keterampilan dasar mengajar guru terhadap perilaku disiplin anak usia dini di kelompok B1 TK Ganesha Denpasar Tahun Pelajaran 2017/2018. Penelitian yang dilaksanakan ini merupakan penelitian kuantitatif dengan jenis penelitian Pre-Experimental Designs dengan desain penelitian yaitu One-Group Pretest-Posttest Design. 


\section{\begin{tabular}{|lll|}
$\mathrm{O}_{1}$ & $\mathrm{X}$ & $\mathrm{O}_{2}$ \\
\hline
\end{tabular} \\ Rancangan One-Group Pretest-Posttest Design (Sumber: Sugiyono, 2017:111)}

$\begin{array}{lll}\text { Keterangan: } & & \\ \mathrm{O}_{1} & =\text { nilai pretest (sebelum diberi } \\ & \text { perlakuan) } \\ \mathrm{X} & \begin{array}{l}=\text { perlakuan (keterampilan dasar } \\ \text { mengajar guru) }\end{array} \\ \mathrm{O}_{2} & \begin{array}{l}\text { = nilai posttest (sesudah diberi } \\ \text { perlakuan) }\end{array}\end{array}$

Data perilaku disiplin anak dalam penelitian ini akan diambil dari skor Posttest. Pre-test dilakukan hanya untuk mengetahui kemampuan awal yang dimiliki oleh anak. Populasi dalam penelitian ini adalah seluruh anak kelompok B1 di TK Ganesha Denpasar pada Semester II Tahun Pelajaran 2017/2018 dengan jumlah siswa sebanyak 20 orang anak, 12 anak laki-laki dan 8 anak perempuan.

Faktor-faktor yang dapat

memengaruhi validitas internal, yang merupakan ancaman terhadap perlakuan yang dilakukan dalam penelitian ini, meliputi (1) kematangan atau maturasi merujuk pada proses perubahan yang terjadi dalam diri subjek yang dijadikan kelompok eksperimen" (Setyosari, 2015:183). Untuk mengontrol validitas internal terkait kematangan dapat dilakukan melalui kelompok kontrol atau kendali yang terdiri atas subjek yang diharapkan memiliki kesamaan pengalaman kematangan dan perkembangan sehingga memungkinkan peneliti dalam melaksanakan penelitian dan membuat kesimpulan tentang perlakuan eksperiman (Setyosari, 2015:184). Pada penelitian ini sampel yang digunakan berada pada tingkatan kelas yang sama yaitu kelas kelompok B1 dan umur yang relatif sama sehingga memiliki tingkat perkembangan yang sama. (2) Pengujian sebelumnya (pretest) dalam penelitian eksperimen dilakukan tes awal sebelum melakukan atau memberikan perlakuan (treatment). Tema yang diterapkan pada saat pretest dilakukan ialah alam semesta dengan subtema benda langit, pretest dan posttest dianalisis untuk mengatahui pengaruh keterampilan dasar mengajar guru terhadap perilaku disiplin anak. (3) Instrumentasi (instrumentation) atau alat ukur dibutuhkan dalam melakukan penelitian. "instrumen adalah pengukuran atau prosedur observasi yang dipakai selama pelaksanaan perlakuaan" (Setyosari, 2015:186). Instrumen dalam penelitian ini digunakan untuk memperoleh data mengenai perilaku disiplin anak.

Beberapa ancaman yang berkaitan dengan validitas eksternal meliputi (1) Interaksi antara perlakuan dengan orang merupakan suatu ancaman bagi validitas eksternal, dalam pengertian bahwa subjek yang terlibat dalam penelitian berbeda atau bertindak berbeda dari subjek yang kita harapkan (Setyosari 2015:193). Interaksi antara perlakuan dengan latar dapat terjadi dalam beberapa situasi, seperti jika subjek mengetahui bahwa mereka menjadi bagian dari penelitian, pengetahuan ini akan menyebabkan hasil yang berbeda (Setyosari 2015:192)/ (3) Interaksi antara perlakuan dengan waktu merupakan suatu faktor penting berkenaan dengan situasi atau kondisi yang kita rancang untuk membuat generalisasi hasil penelitian. Validitas eksternal pada penelitian dapat dikontrol dengan cara melaksanakan pengamatan dan wawancara secara kualitatif yang menyatakan bahwa tidak ada orang-orang dan latar tertentu atau khusus dan peristiwa-peristiwa historis yang dapat menghambat generalisasi hasil penelitian. Selain itu agar lebih mudah mengontrol ancaman validitas eksternal di lakukan dengan membatasi populasi. Pada penelitian ini menggunakan populasi anak Kelompok B1 TK Ganesha Denpasar.

Variabel dalam penelitian ini terdiri atas variabel bebas (independen) dan variabel terikat (dependen). Variabel bebas yang dimaksud dalam penelitian ini adalah keterampilan dasar mengajar guru, sedangkan variabel terikat dalam penelitian ini adalah perilaku disiplin.

Data yang dikumpulkan adalah data perilaku disiplin anak kelompok B1 di TK Ganesha Denpasar Tahun Pelajaran $2017 / 2018$. Metode yang digunakan untuk 
mengumpulkan data perilaku disiplin dalam penelitian ini adalah metode non tes dalam bentuk observasi. Data observasi didapatkan dari pre-test dan post-test sebelum dan sesudah diterapkannya keterampilan dasar mengajar guru dalam proses pembelajaran anak kelompok B1 di TK Ganesha Denpasar Tahun Pelajaran 2017/2018.

Data observasi pada perilaku disiplin anak merupakan jenis data yang bersifat kuantitatif berupa angka-angka. Alat pegumpulan data dalam penelitia ini berupa lembar observasi yang dilengkapi rubrik penilaian perilaku disiplin.

Teknik analisis yag digunakan untuk menganalisis data perilaku disipli aak adalah statistik inferensial dengan menggunakan uji-t dengan menggunakan rumus uji varians.

\section{HASIL DAN PEMBAHASAN}

Deskripsi data dalam hasil penelitian ini memaparkan tentang mean, uji normalitas dan uji hipotesis. Berdasarkan data perilaku disiplin anak kelompok B1 TK Ganesha Denpasar yang dibelajarakan melalui penerepan keterampilan dasar mengajar guru. Untuk data observasi sebagai instrumen dalam penelitian perilaku disiplin anak kelompok B1 TK Ganesha Denpasar yang digunakan sebanyak 5 butir indikator. Banyaknya anak didik yang dianalisis data post-test perilaku disiplin pada kelompok B1 TK Ganesha Denpasar sebanyak 20 peserta didik, yang terdiri dari 12 anak laki-laki dan 8 anak perempuan. Penelitian dilaksanakan dalam II pekan, penelitian ini dibagi menjadi pretest dan post-test.

Deskripsi data nilai akhir untuk perilaku disiplin anak yang memaparkan rata-rata (mean), gain score dan uji normalitas sebaran data (Chi-kuadrat), dan rentangan disajikan pada tabel 1 sebagai berikut

Tabel 1. Rekapitulasi Hasil Deskripsi Nilai Perilaku Disiplin Kelompok B1 TK Ganesha Denpasar Tahun Pelajaran 2017/2018

\begin{tabular}{llll}
\hline Hasil Analisis & Pre-test & Hasil Analisis & Post-test \\
\hline Mean & 71,8 & Mean & 85,9 \\
Minimum & 60 & Minimum & 75 \\
Maksimum & 83 & Maksimum & 97 \\
Rentangan & 24 & Rentangan & 23 \\
Banyak Kelas & 5 & BanyakKelas & 5 \\
Panjang Kelas & 5 & PanjangKelas & 5 \\
\hline
\end{tabular}

Hasil pre-test perilaku disiplin anak diperoleh nilai rata-rata sebesar 71,8 dan hasil post-test perilaku disiplin diperoleh nilai rata-rata sebesar 85,9. Dari data tersebut menunjukkan bahwa perilaku disiplin anak kelompok B1 mengalami peningkatan dari sebelum dan sesudah diberikan perlakuan (treatment) melalui penerapan keterampilan dasar mengajar guru.

Gambar secara lebih jelas mengenai distribusi frekuensi pengembangan adanya pegaruh perilaku disiplin anak sebelum dibelajarkan dengan menerapkan keterampilan dasar mengajar guru pada anak kelompok B1 TK Ganesha Denpasar dapat dilihat pada gambar 1. sebagai berikut.

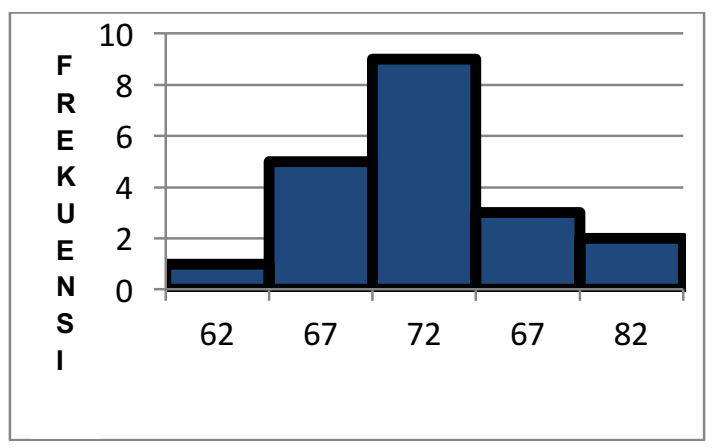

Gambar 1.

Grafik Histogram Perilaku Disiplin Anak Sebelum Diberikan Treatment 
Pada grafik histogram perilaku disiplin anak sebelum diberikan perlakuan (treatment) keterampilan dasar mengajar guru dapat dilihat bahwa anak yang memiliki rentangan 60-64 adalah sebanyak 2 orang dengan nilai tengah 62 . Rentangan 65-69 adalah sebanyak 3 orang dengan nilai tengah 67 . Rentangan $70-74$ adalah sebanyak 9 orang dengan nilai tengah 72 . Rentangan 75-79 adalah sebanyak 5 orang dengan nilai tengah 77 . Rentangan 80-84 adalah sebanyak 1 orang dengan nilai tengah 83.

$\begin{array}{ccc}\text { Gambar secara lebih jelas } \\ \text { mengenai } & \text { distribusi frekuensi }\end{array}$
pengembangan adanya pegaruh perilaku disiplin anak sesudah dibelajarkan dengan menerapkan keterampilan dasar mengajar guru pada anak kelompok B1 TK Ganesha Denpasar dapat dilihat pada gambar 2 . sebagai berikut.

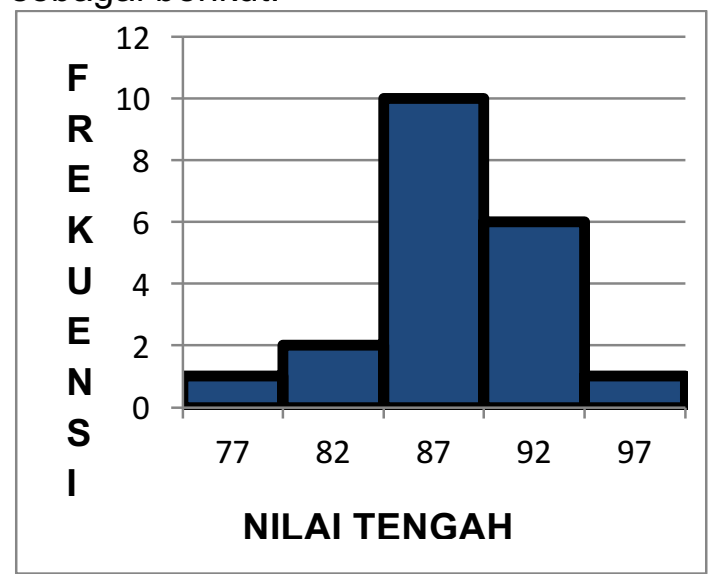

Gambar 2

Grafik Histogram Perilaku Disiplin Anak Sesudah Diberikan Treatment
Uji normalitas data perilaku disiplin anak menggunakan rumus Chi-kuadrat. Berdasarkan hasil uji normalitas kriteria pengujian jika $X^{2}{ }_{h i t}<X^{2}$ tabel, maka $h_{0}$ diterima (gagal ditolak) yang berarti data berdistribusi normal. Sedangkan taraf signifikansi adalah $5 \%$ dan derajat kebebasannya $n-1$. Jadi hasil uji normalitas pada pemberian post-test, diperoleh Chi Kuadrat hitung $\left(X_{\text {hitung }}^{2}=1,621\right)$ kemudian nilai tersebut dibandingkan dengan Chi Kuadrat tabel $\left(X_{\text {tabel }}^{2}=11,07\right)$.

Berdasarkan hal itu maka uji statistik yang digunakan dalam penelitian ini adalah uji-t dengan menggunakan rumus uji varians. Setelah perhitungan selesai kemudian dilakukan uji signifikansi yaitu dengan cara membandingkan antara $t_{\text {hitung }}$ yag diperoleh dengan $t_{\text {tabel }}$. Dengan kriteria jika $t_{\text {hitung }}<\mathrm{t}_{\text {tabel }}$, maka $\mathrm{H}_{0}$ diterima dan $\mathrm{H}_{\mathrm{a}}$ ditolak, dan jika $t_{\text {hitung }}>t_{\text {tabel }}$, maka $\mathrm{H}_{0}$ ditolak dan $\mathrm{H}_{\mathrm{a}}$ diterima pada taraf signifikansi $5 \%$ dengan $\mathrm{dk}=\mathrm{n}-1$.

$\mathrm{H}_{0}$ menyatakan bahwa tidak terdapat pengaruh yang signifikan penerapan keterampilan dasar mengajar guru terhadap perilaku disiplin anak kelompok B1 di TK Ganesha Denpasar tahun pelajaran 2017/2018. Sedangkan hipotesis alternative $\left(\mathrm{H}_{\mathrm{a})}\right.$ menyatakan bahwa terdapat pengaruh yang signifikan penerapan keterampilan dasar mengajar guru terhadap perilaku disiplin anak kelompok B1 di TK Ganesha Denpasar tahun pelajaran 2017/2018.

Dari hasil analisis uji hipotesis yang dilaksanakan diperoleh hasil yang disajikan pada tabel 01 sebagai berikut.

Tabel 01. Rekapitulasi analisis Uji-t

\begin{tabular}{cccccc}
\hline No & Populasi & $\mathrm{N}$ & $\mathrm{t}_{\text {hitung }}$ & $\mathrm{t}_{\text {tabel }}$ & Status \\
\hline 1 & Kelompok B1 & 20 & 25,18 & 2,093 & $\mathrm{H}_{0}$ ditolak dan $\mathrm{H}_{\mathrm{a}}$ diterima \\
\hline
\end{tabular}

Dari hasil analisis diperoleh $t_{\text {hitung }}=$ 25,18 dan $t_{\text {tabel }}=2,093$ pada taraf signifikansi $5 \%(\alpha=0,05)$ dengan $d k=n-$ $1=20-1=19$. Oleh karena itu $t_{\text {hitung }}=25,18>$ $t_{\text {tabel }}=2,093$ maka $H_{0}$ yang menyatakan bahwa tidak terdapat pengaruh yang signifikan penerapan keterampilan dasar mengajar guru terhadap perilaku disiplin anak kelompok B1 di TK Ganesha
Denpasar tahun pelajaran 2017/2018 ditolak, dan berarti $\left(H_{a}\right)$ yang menyatakan bahwa terdapat pengaruh yang signifikan penerapan keterampilan dasar mengajar guru terhadap perilaku disiplin anak kelompok B1 di TK Ganesha Denpasar tahun pelajaran 2017/2018 diterima. Dapat dikatakan bahwa terdapat pengaruh penerapan keterampilan dasar mengajar 
guru terhadap perilaku disiplin anak kelompok B1 di TK Ganesha Denpasar tahun pelajaran $2017 / 2018$.

Usia dini sebagai masa yang sangat cemerlang untuk dilakukannya pendidikan. Pendidikan yang tepat sangat dibutuhkan khususnya untuk mengembangkan perkembangan sosial anak, sangat penting untuk membiasakan perilaku-perilaku yang positif sejak usia dini. Melalui penanaman perilaku disiplin anak dapat mengembangan perkembangan sosialnya, penanaman perilaku disiplin dapat dimulai dengan hal-hal sederhana pada kehidupan sehari-hari anak seperti mengingatkan anak untuk mengembalikan barang yang ia pakai jika sudah selesai dipakai, mengingatkan anak untuk tidak membuang sampah sembarangan, dengan mengingatkan secara terus-menerus maka anak akan terbiasa dan akan tertanam dalam diri anak untuk berperilaku disiplin. Menurut (Fidesrinur, 2015:6) dalam penanaman perilaku disiplin diperlukan $5 \mathrm{~K}$, yaitu konsensus yang berarti adanya kerja sama antara orang tua dan guru dalam membangun karakter anak, komitmen yang berarti adanya ketaatan dan tanggung jawab orang tua dan guru dalam membagun karakter anak, konsisten berarti orang tua dan guru ajeg dalam proses penerapan karakter, kontinu yang berarti orang tua dan guru terus menerus melakukan kegiatan untuk membangun karakter anak sehingga menjadi kebiasaan dalam diri anak dan membentuk suatu karakter, konsekuensi yang berarti adanya hukuman bagi orang tua, guru, dan anak apabila melanggar kesepakatan.

Seorang guru harus memiliki keterampilan dasar mengajar yang baik dalam menanamkan perilaku disiplin pada anak seperti dapat mengelola kelas agar pembelajaran menjadi menarik dan anak fokus sehingga tujuan pembelajaran dapat tercapai. Dalam penelitian yang dilakukan oleh Astiti (2017) menyatakan bahwa rendahnya nilai karakter yang dimiliki oleh anak disebabkan oleh bagaimana pengelolaan pembelajaran yang diberikan oleh guru serta sarana dan prasarana yang terbatas. Dari pendapat tersebut dapat berarti bahwa guru harus terampil dalam mengajar di dalam kelas.

Keterampilan bertanya merupakan "keterampilan yang digunakan untuk mendapatkan jawaban atau balikan dari orang lain" (Barnawi, 2012:202). Menurut Saud (2010:62) keterampilan bertanya dibedakan atas keterampilan bertanya tingkat dasar dan keterampilan bertanya tingkat lanjut. Keterampilan bertanya tingkat dasar ialah kemampuan guru dalam mengajukan pertanyaan untuk mengetahui daya ingat peserta didik. Sedangkan, keterampilan bertanya tingkat lanjut ialah kemampuan bertanya seorang guru dalam pembelajaran untuk mengetahui kemampuan berpikir peserta didik yang lebih kompleks. Dalam penelitian ini salah satu contoh keterampilan bertanya guru yaitu memberikan pertanyaan kepada seluruh anak didalam kelas terlebih dahulu, selanjutnya guru juga bertanya secara individu kepada anak secara bergantian. Dari kegiatan bertanya tersebut anak akan lebih fokus dan termotivasi sehingga anak tetap tertib dan berada didalam kelas saat proses pembelajaran. Menurut Rasto $(2015: 94)$ kegunaan bertanya yaitu memotivasi anak, membangkitkan minat dan rasa ingin tahu anak tentang suatu topik.

Selain memiliki keterampilan untuk bertanya guru juga harus mampu memberikan penguatan kepada anak-anak dalam proses pembelajaran. Penguatan adalah "respon terhadap suatu tingkah laku yang dapat meningkatkan kemungkinan berulangnya kembali tingkah laku tersebut" (Saud, 2010:65). Menurut Helmiati (2013:74) penguatan bersifat verbal ataupun non verbal. Penguatan verbal contohnya seperti kata-kata pujian, penghargaan, persetujuan. Misalnya: "pintar sekali", "bagus", "betul", "seratus buat nani". Sedangkan penguatan non verbal contohnya berupa gerak mimik badan, misalnya: acungan jempol, senyuman, kerut kening, wajah cerah. Dalam penelitian ini guru memberikan pujian secara verbal setiap kali anak merapikan barang-barang ataupun mainan pada tempatnya, dan guru juga memberikan penguatan ketika anak malu, 
malas, ataupun tidak mau mengikuti pembelajaran dengan tertib dan disiplin. Dari pemberian penguatan anak menjadi lebih taat akan peraturan didalam kelas, anak menjadi lebih mengerti hal apa yang baik untuk dilakukan dan hal-hal apa yang kurang baik untuk dilakukan. Menurut Rasto (2015:112) penguatan yang efektif dapat memodifikasi perilaku anak ke arah yang diinginkan, penguatan adalah keterampilan yang digunakan guru untuk meningkatkan frekuensi perilaku positif (diinginkan dari anak) atau untuk mengurangi perilaku negatif (tidak diinginkan dari anak).

Keterampilan terakhir yang diterapkan dalam penelitian ini yaitu keterampilan mengelola kelas. Menurut Asril (2011:7273) keterampilan mengelola kelas merupakan keterampilan guru untuk menciptakan dan memelihara kondisi belajar yang optimal dan mengembalikan ke kondisi yang optimal jika terjadi gangguan, baik dengan cara mendisiplinkan ataupun melakukan kegiatan remedial. Komponen-komponen keterampilan mengelola kelas menurut Helmiati (2013:79-81) terdiri dari dua yaitu keterampilan yang berhubungan dengan penciptaan dan pemeliharaan kondisi belajar yang optimal (bersifat preventif) seperti memusatkan perhatian anak, menunjukkan sikap tanggap, membagi perhatian, memberikan petunjuk-petunjuk yang jelas, memberi teguran secara bijaksana, memberi penguatan ketika diperlukan. Dan juga keterampilan yang berhubungan dengan pengembangan kondisi belajar yang optimal, seperti memodifikasi tingkah laku, pengelolaan kelompok, menemukan dan memecahkan tingkah laku yang menimbulkan masalah. Dalam penelitian ini guru mengajak anak bermain diluar kelas dan menutup pintu kelas agar anak bermain bersama dihalaman sekolah dan anak dari kelas yang berbeda tetap dapat saling mengenal dan bermain bersama, selain itu guru juga melakukan kegiatan secara bergantian dan dengan melaksanakan kegiatan secara bergantian anak menjadi lebih sabar dan mau mengantri.

\section{PENUTUP}

Berdasarkan hasil penelitian yang diperoleh bahwa terdapat pengaruh yang signifikan penerapan keterampilan dasar mengajar guru terhadap perilaku disiplin anak kelompok B1 di TK Ganesha Denpasar tahun pelajaran 2017/2018, dengan nilai $t_{\text {hitung }}=25,18$ dan $t_{\text {tabel }}=2,093$ dengan taraf signifikansi $5 \%$ dan derajat kebebasan 19. Dengan demikian penerapan keterampilan dasar mengajar guru berpengaruh terhadap perilaku disiplin anak kelompok B1 di TK Ganesha Denpasar tahun pelajaran 2017/2018.

Dengan membiasakan anak berperilaku disiplin diharapkan bahwa ketika anak tumbuh dewasa, meraka akan menjadi manusia-manusia yang tidak saja pandai dan berpengetahuan luas, namun juga bermoral tinggi, dan berakhlak mulia, serta berbudi luhur. perilaku disiplin yaitu sikap taat terhadap aturan sehari-hari serta sikap sabar yang dapat ditunjukkan dengan melakukan kegiatan anak tidak di dalam kelas saat jam istirahat, anak berada di kelas selama kegiatan pembelajaran, anak mau membereskan alat tulis ke dalam loker, anak mau mengantri saat kegiatan tertentu (mencuci tangan, mengumpulkan tugas, dan bersalam dengan guru untuk pulang), serta anak tidak ditunggu orang tua di sekolah. Perilaku disiplin dapat dikenalkan dan dibiasakan dirumah dan sekolah, oleh karena itu harus ada kerja sama yang baik antara guru dan orang tua. Banyak faktor yang dapat mempengaruhi perilaku disiplin, salah satu faktor rendahnya perilaku disiplin yang dimiliki oleh anak disebabkan oleh bagaimana pengelolaan pembelajaran yang diberikan oleh guru serta sarana dan prasarana yang terbatas.

Adapun saran yang ingin disampaikan melalui penelitian ini adalah Keterampilan seorang guru dalam mengelola proses pembelajaran sangatlah penting dalam membiasakan anak untuk berperilaku disiplin. Keterampilan yang dapat diterapkan guru dalam proses belajar-mengajar adalah keterampilan dasar mengajar bertanya, keterampilan memberi penguatan, serta keterampilan mengelola kelas. Dalam menerapkan 
keterampilan dasar mengajar guru disesuaikan dengan tujuan pembelajaran, agar tujuan pembelajaran yang ingin dicapai dapat tercapai. Salah satu cara agar anak memiliki perilaku disiplin yaitu dengan mengelola kelas semenarik mungkin seperti membagi anak menjadi beberapa kelompok. Salah satu cara lain untuk menghadapi anak yang kurang disiplin di kelas, yakni dengan bertanya apa yang ia ingini atau ia rasakan, dengan menunjukkan perhatian melalui pertanyaan tersebut anak akan lebih memerhatikan apa yang dilakukan guru.

\section{DAFTAR PUSTAKA}

Astiti, Ida Ayu Made Putri. 2017. Pengaruh Permainan Tradisional Hompimpa Berbantuan Media Ogoh-Ogoh Terhadap Nilai Karakter Anak Usia Dini Kelompok B1 TK Saraswati Sukawati. Singaraja: Universitas Pendidikan Ganesha. Tersedia pada

https://ejournal.undiksha.ac.id/inde x.php/JJPAUD/article/viewFile/113 49/7259. (diakses tanggal: 24 Januari 2018)

Aulina, Choirun Nisak. 2013. Penanaman Disiplin Pada Anak Usia Dini. Sidoarjo: Universitas Muhammadiyah Sidoarjo. Tersedia pada

http://ojs.umsida.ac.id/index.php/p edagogia/article/viewFile/45/51. (diakses tanggal: 24 Januari 2018)

Barnawi, dan Mohammad Arifin. 2012. Etika Dan Profesi Kependidikan. Jogjakarta: Ar-Ruzz Media.

Fidesrinur, Dkk. 2015. Pedoman Penanaman Sikap Pendidikan Anak Usia Dini. Jakarta: Direktorat Pembinaan Pendidikan Anak Usia Dini.

Helmiati. 2013. Micro Teaching. Yogyakarta: Aswaja Pressindo
Rasto. 2015. Pembelajaran Mikro. Bandung: Alfabeta.

Saud, Udin Syaefudin. 2010. Pengembangan Profesi Guru. Bandung: Alfabeta.

Setyosari, Punaji. 2015. Metodologi Penelitian Pendidikan Dan Pengembangan. Jakarta: Prenadamedia Group

Sugiyono. 2017. Metode Penelitian Pendidikan (Pendekatan Kuantitatif, Kualitatif, dan R\&D). Bandung: Alfabeta.

Wahyuni, Lisa. 2015. Hubungan Keterampilan Mengajar Guru Dengan Minat Belajar Siswa Kelas $\checkmark$ SD Negeri Segugus I Kecamatan Simpur Kabupaten Hulu Sungai Selatan Provinsi Kalimantan Selatan Tahun Ajaran 2014/2015. Skripsi Fakultas IImu Pendidikan, Universitas Negeri Yogyakarta. Tersedia pada (diakses tanggal: 24 Januari 2018) 